\title{
De invloed van bedrijfsstrategieën op de prestaties van kleine, familiale ondernemingen*
}

De casus steen- en buizenbakkerij Dumoulin in Langemark en Wijtschate, ca. 1922-1981

Kim Descheemaeker

TSEG $18(2): 5^{-37}$

DOI: $10.52024 /$ tseg 8428

\begin{abstract}
The impact of compagny stragegies on the performance of small family compagnies. Dumoulin brick and pipe factory in Langemark and Wijtschate (Belgium), c. 1922-1981.

The case of the Dumoulin brick and pipe factory (c. 1922-1981) in Langemark and Wijtschate in the southern Westhoek (Belgium) can be regarded as a typical example of a small, family-owned, West Flemish company that tried to survive in a turbulent business environment. In the twentieth century, the ceramic sector was characterized by large-scale technological changes and a rearrangement of the industrial landscape. This article reconstructs and analyzes the life cycle of the Dumoulin brick and pipe factory. The use of an explicit theoretical framework and the regional focus contribute to the international historiography of small and medium-sized enterprises and family businesses, as well as to the socio-economic history of West Flanders.
\end{abstract}

De casus van steen- en buizenbakkerij Dumoulin (ca. 1922-1981) in Langemark en Wijtschate in de zuidelijke Westhoek kan beschouwd

* Dit artikel kwam tot stand in nasleep van het project 'Dichter bij de Mensen' van CO . Graag bedank ik de medewerkers van dit project, namelijk $\mathrm{CO}_{7}$, RLICC-KU Leuven, ETWIE, de lokale heemkundigen, vrijwilligers en respondenten. Daarnaast wil ik ook de collega's van Liberas en in het bijzonder directeur Peter Laroy en dr Christoph De Spiegeleer bedanken voor hun waardevolle feedback en de kans om aan dit project te werken. Tot slot gaat mijn dank uit naar de anonieme referenten en de redactie van TSEG voor hun grondige lezing, kritische blik en waardevolle commentaar. 
worden als een typisch voorbeeld van een kleine, familiale, WestVlaamse onderneming die zich staande probeerde te houden in een turbulente periode. De grofkeramische sector werd in de twintigste eeuw immers gekenmerkt door grootschalige technologische veranderingen en een herschikking van het industriële landschap. In dit artikel wordt de levensloop van steen- en buizenbakkerij Dumoulin gereconstrueerd en geanalyseerd. De centrale onderzoeksvraag is wat het innovatieve potentieel van het bedrijf gedurende haar levensloop was, of en hoe het bedrijf hierdoor kon inspelen op een veranderende omgeving en of dit vervolgens de prestaties van het bedrijf beïnvloedde. Door het gebruik van een expliciet theoretisch kader en de regionale focus wordt een bijdrage geleverd aan zowel de internationale historiografie met betrekking tot kleine en middelgrote ondernemingen (kmo's) en familiebedrijven, als aan de sociaaleconomische geschiedenis van WestVlaanderen.

In België wordt vooral vanaf de jaren 1960-1970 aandacht besteed aan bedrijfsgeschiedenis. ${ }^{1}$ Ondanks de initiatieven op dit vlak liggen nog heel wat onderzoeksmogelijkheden open. Zo blijven microhistorische case studies van bedrijven nog vaak beperkt tot gelegenheidspublicaties, waardoor vooral relatief succesvolle bedrijven onder de loep worden genomen. Bovendien is er nog weinig aandacht voor kmo's en familiebedrijven. ${ }^{2}$ Zeker in België is onderzoek hiernaar zeer beperkt.

1 In navolging van de Angelsaksische benadering besteedde het Centrum voor Economische Studiën aan de KU Leuven vooral aandacht aan grote ondernemingen en holdings. Het in 1971 aan de Universiteit Antwerpen opgerichte Centrum voor Bedrijfsgeschiedenis ondernam initiatieven om archieven van ondernemingen, instellingen en personen die een stempel gedrukt hebben op het Belgische bedrijfsleven op te sporen en te bewaren. In 2009 werd dit Centrum geïntegreerd in het Studiecentrum voor Onderneming en Beurs, waarna het onderzoek zich steeds meer ging toespitsen op de financiële geschiedenis. Zie onder meer F. de Goey en G. Devos, 'Ontstaan en uitbouw van de bedrijfsgeschiedenis', in: C. Vancoppenolle (red.), Een succesvolle onderneming. Handleiding voor het schrijven van een bedrijfsgeschiedenis (Brussel 2002) 64-65; Centrum voor Bedrijfsgeschiedenis, 'Verslag van de activiteiten van het centrum voor de periode 2005-2011', http://www.scob.be/publicat/CBG2011.pdf, geraadpleegd op 7 augustus 2019; H. Houtman-De Smedt, 'Overzicht van de publicaties van het Centrum voor Bedrijfsgeschiedenis' (2016) http://www.scob.be/publicat/OVERZICHT\%2oPUBLICATIES\%2oCentrum\%2O voor\%2oBedrijfsgeschiedenis.pdf, geraadpleegd op 7 augustus 2019; SCOB, 'Publications \& Reports', http://www.scob.be/publications-technicalreports.html, geraadpleegd op 7 augustus 2019.

2 In Nederland is er al enig onderzoek naar familiebedrijven gebeurd. Zo werd de term 'familisme' geintroduceerd door Frederik van Heek. De term verwijst naar de wijze van bedrijfsvoering waarbij het kapitalistische winststreven ondergeschikt is aan de versteviging van de sociale positie van de familie van de ondernemers. Internationaal krijgt historisch onderzoek naar familiebedrijven vooral sinds de laatste decennia meer aandacht. In deze studies worden echter voornamelijk bedrijven die al verschillende generaties in familiehanden zijn voor het voetlicht gebracht en is er bijzondere aandacht voor de familiale opvolging binnen het bedrijf. Aangezien de hier behandelde casus een bedrijf betreft dat slechts 
Nochtans maakten en maken kmo's een belangrijk deel uit van het Belgische economische weefsel. ${ }^{3}$

Bij historisch onderzoek naar bedrijven ontbreekt bovendien vaak een (expliciet) theoretisch kader. Dit kan evenwel helpen om de specifieke dynamiek van bedrijfshistorische ontwikkelingen te vatten. ${ }^{4}$ In Nederland ondernam de Posthumus-Sneller school al vanaf de jaren 1920 door theorieën geschraagde empirische studies naar de ontwikkeling van de Nederlandse economie in de vroegmoderne tijd. Stap voor stap werd met case studies de levensloop van verschillende (deel) industrieën van naderbij onderzocht. Hierbij was er aandacht voor diverse interne en externe factoren, waaronder arbeid, kapitaal, technologie, ondernemerschap, overheidsbeleid, (inter)nationale markten enzovoort. ${ }^{5}$ Deze bijdrage knoopt bij deze methode aan met een aan een theoretisch kader getoetst micro-onderzoek naar een concreet bedrijf.

West-Vlaanderen wordt tot op heden gekenmerkt door een flexibel economisch weefsel gebaseerd op lokaal verankerde familiebedrijven. Om de sociaaleconomische en industriële ontwikkeling van de regio te begrijpen, is het dan ook van belang om de levensloop van deze familiebedrijven onder de loep te nemen. Brecht Demasure schreef een diepgaande socio-economische streekgeschiedenis van Midden- en Zuid-West-Vlaanderen tussen 1840 en 1970. Zijn onderzoek is sterk gebaseerd op statistisch materiaal, maar werd ook verdiept met een aantal case studies. ${ }^{6}$ De studie van Demasure richt zich vooral op de regio Kortrijk-Roeselare. Voor de Westhoek is dergelijk onderzoek niet voorhanden. Een case study van steen- en buizenbakkerij Dumoulin levert

\footnotetext{
in handen bleef van één generatie, zou het te ver leiden om deze theorievorming hier op te nemen. Het concept 'familisme' komt wel aan bod in dit onderzoek. Zie onder meer F. van Heek, Stijging en daling op de maatschappelijke ladder. Een onderzoek naar de verticale sociale mobiliteit (Leiden 1945); A.L. Van Schelven, Onderneming en familisme. Opkomst, bloei en neergang van de textielonderneming Van Heek \& Co te Enschede (Leiden 1984) en D. Arnoldus, Family, family firm, and strategy. Six Dutch family firms in the food industry 1880-1970 (Amsterdam 2002); A. Colli, C. Howorth en M. Rose, 'Long-term perspectives on family business', Business History 55:6 (2013) 841-854.

3 Zie bijvoorbeeld O. Ongena, Een geschiedenis van het sociaaleconomisch overleg in Vlaanderen (1945-2010). 25jaar SERV(Gent 2010) 93-94.

4 J.F.E. Bläsing en T. Langenhuyzen, 'De verhouding tussen theorie en praktijk', in: Vancoppenolle (red.), Een succesvolle onderneming, 33-34; S. De Caigny, E. Buyst en C. Vancoppenolle, 'Heuristiek en methode: de (on)mogelijkheid van bedrijfsgeschiedenis in België, $19^{\text {de }}-20^{\text {ste }}$ eeuw', $B T N G / R B H C$ 33:3-4 (2003) 319-365, 335.

5 K. Davids, 'Great transformations. Economic history and the history of technology', TSEG 11:2 (2014) 111-130, 114-115.

6 B. Demasure, Overwerken mensen. Een sociaaleconomische streekgeschiedenis van Midden-en ZuidWest-Vlaanderen (Brugge 2012).
} 
daarmee ook een bijdrage aan de streekgeschiedenis van de Westhoek en bij uitbreiding van West-Vlaanderen.

In dit artikel lichten we eerst het theoretische kader toe dat we uitwerkten om de levensloop van een familiebedrijf te analyseren en waarderen. Vervolgens wordt de gehanteerde methodologie toegelicht en worden de gebruikte bronnen per brontype besproken. Daarna toetsen we de levensloop van steen- en buizenbakkerij Dumoulin aan het theoretische kader. In de conclusie koppelen we ten slotte terug naar de vraagstelling, zoals geformuleerd in de inleiding, en bespreken we de bruikbaarheid van het theoretisch kader voor de waardering van deze specifieke casus maar ook in het algemeen.

\section{Een theoretisch kader als werkinstrument voor de studie van de levensloop van een familiebedrijf}

In dit artikel onderzoeken we de prestaties van steen- en buizenbakkerij Dumoulin doorheen haar bestaan. We wensen echter nog een stap verder te gaan en pogen te begrijpen waarom het bedrijf op een bepaald moment in haar levensloop op een bepaalde wijze presteerde. We willen met andere woorden achterhalen of er een verband bestaat tussen de prestaties van het bedrijf op een bepaald punt in haar levensloop en de strategieën en organisatiestructuren die het bedrijf op dat moment kenmerkten.

Om de interactie tussen de bedrijfsstrategieën en prestaties van de onderneming te analyseren op verschillende niveaus is een breed theoretisch kader nodig. Wat 'goed presteren' inhoudt voor een bedrijf varieert naargelang de historische, culturele en regionale context. Zeker bij familiebedrijven is performance niet louter verbonden met financiële opbrengst, maar ook met bijvoorbeeld status, maatschappelijke positie en machtsverwerving op andere vlakken (sociaal en politiek kapitaal). ${ }^{7}$ Door af te stappen van een zuiver financiële analyse van de prestaties, wordt het niet alleen mogelijk om de complexe historische en culturele context mee te nemen, maar ook om onderzoek te doen naar bedrijven waarvan geen of onvolledige financiële bronnenreeksen voorhanden zijn. Daar staat tegenover dat de performance van een bedrijf in deze brede betekenis moeilijk in absolute termen is uit te drukken: enkel een relatieve evaluatie ten opzichte van eerdere of latere perioden is mogelijk.

7 Zie hiervoor onder meer het concept 'familisme' van Frederik van Heek en recenter het onderzoek van Andrea Colli. 
Voor de analyse van de performance maken we hier gebruik van de parameters die Andrea Colli onderscheidde op basis van literatuur en eigen onderzoek: survival en longevity (voortbestaan (als een familiebedrijf)), embeddedness (inbedding in de sociale en maatschappelijke omgeving), reputation, en sustainability (de mogelijkheid om in privéen familiehanden te blijven bij groei/uitbreiding - sociaal kapitaal opbouwen en behouden). ${ }^{8}$ Voor de analyse van de strategieën en de organisatiestructuren van het bedrijf gedurende zijn levensloop wordt sterk gesteund op twee theorieën, namelijk de instrumentele innovatietheorie geformuleerd door Arie de Geus in zijn boek The Living Company en de theorie van creatieve destructie zoals naar voren gebracht door Richard Foster en Sarah Kaplan. ${ }^{9}$ Daarnaast wordt gebruik gemaakt van de theorie over de verspreiding van innovaties van Everett Rogers. ${ }^{10} \mathrm{We}$ combineren en herformuleren deze theorieën hier zelf tot een praktisch werkinstrument.

Volgens de theorie van De Geus is het voortbestaan van een bedrijf afhankelijk van de mate waarin het door aanpassingen van zijn interne factoren kan inspelen op een veranderende externe omgeving. De externe factoren waarmee een bedrijf volgens De Geus in interactie treedt, omvatten onder meer de beperkingen en verwachtingen van de omgeving, waaronder institutionele, sociale, culturele en politieke omstandigheden; en de wijzigende markt met onder meer vraag en aanbod, arbeids- en kapitaalmarkt, en concurrentie. De interne factoren omvatten het productieproces, de productiemiddelen en de organisatievorm van het bedrijf, maar ook de wijze van managen. Verondersteld wordt dat het bedrijf een levenscyclus doormaakt, waarbij een vroegtijdige neergang slechts voorkomen kan worden door in te spelen op de veranderende omgeving en dus door innovatieve strategieën te introduceren. De capaciteit van bedrijven om dergelijke strategieën te ontwikkelen hangt volgens De Geus af van een aantal interne factoren die verband houden met het management en de bedrijfscultuur: sensitiviteit voor

8 A. Colli, 'Contextualizing performance of family firms. The perspective of business history', Family Business Review 25:3 (2012) 243-257.

9 A. de Geus, The living company. Habits for survival in a turbulent business environment (Boston 2002); R. Foster en S. Kaplan, Creative destruction. Why companies that are built to last underperform the market - and how to successfully transform them (New York 2001). Zonder dit expliciet te benoemen werd een gelijkaardig kader al gebruikt voor een vergelijkende studie naar de levensduur van enkele familiebedrijven in Duitsland en Spanje: M. Fernandez Moya, P. Fernández Pérez en C. Lubinski, 'Standing the test of time. External factors influencing family firm longevity in Germany and Spain during the twentieth century',Journal of Evolutionary Studies in Business 5:1 (2020) 221-264.

10 E.M. Rogers, Diffusion of innovations (New York 2003). 
de omgeving, een sterke identiteit, een open leeromgeving, tolerantie voor activiteiten in de marge en een conservatieve financiering. Bedrijven kunnen op verschillende manieren innoveren: naast productinnovatie en -diversificatie zijn ook procesinnovatie, vermarktingsinnovatie en organisatorische innovatie mogelijk. ${ }^{11}$

In de economische geschiedenis worden daarenboven onder meer de timing, diffusie en impact van innovaties onderzocht om de bijdrage van technologische veranderingen aan economische groei te achterhalen. Dezelfde parameters kunnen ook op microschaal inzicht bieden in de bijdrage van bovenstaande innovaties aan de levensloop van het bedrijf. De innovaties kunnen aldus gewaardeerd worden naar hun impact en naar het ogenblik van toepassing door het bedrijf.

In navolging van Schumpeter legt de theorie van de creatieve destructie, zoals geformuleerd door Foster en Kaplan, de nadruk op de disruptieve kracht van innovaties voor een sector of maatschappij. Foster en Kaplan hanteren een driedelige rangschikking om de impact van de innovaties te klasseren. Hierbij omvatten incrementele of geleidelijke innovaties de dagelijkse verbetering van de bestaande producten, processen of systemen. Radicale of baanbrekende innovaties omvatten de introductie van nieuwe producten, processen of systemen binnen de kerncapaciteiten van de onderneming. Tot slot bestaat een transformationele innovatie uit de introductie van totaal nieuwe producten, diensten, businessmodellen enzovoort, gericht op nieuwe markten en klantbehoeften. ${ }^{12}$

Niet enkel de orde van grootte van een innovatie maar ook het moment van de introductie speelt een belangrijke rol in de waardering van innovatieve strategieën. Hiervoor volgen we de klassering volgens de innovatietheorie van Rogers. Deze theorie, die oorspronkelijk gebaseerd is op de diffusie van vernieuwingen onder consumenten, kent een indeling in vijf fasen waarbij in iedere fase een volgende groep de vernieuwing accepteert. De volgende categorieën worden onderscheiden: innovators, early adopters, early majority, late majority en achterblijvers. ${ }^{13}$ Opgemerkt moet worden dat de theorie uitgaat van innovaties die zich uiteindelijk volledig verspreiden, terwijl dit niet voor alle innovaties het geval is. Zeker op het vlak van vermarktingsinnovatie is er vaak sprake van een onvolledige diffusie, omdat de innovatie niet steeds als een verbetering wordt gepercipieerd. ${ }^{14}$

11 De Geus, The living company, 6-7, 27, 133 .

12 Foster en Kaplan, Creative destruction, 106-114.

13 Rogers, Diffusion of innovations.

14 T.S. Robertson, 'The process of innovation and the diffusion of innovation', Journal of Marketing 31 (1967) 1, 16-17. 


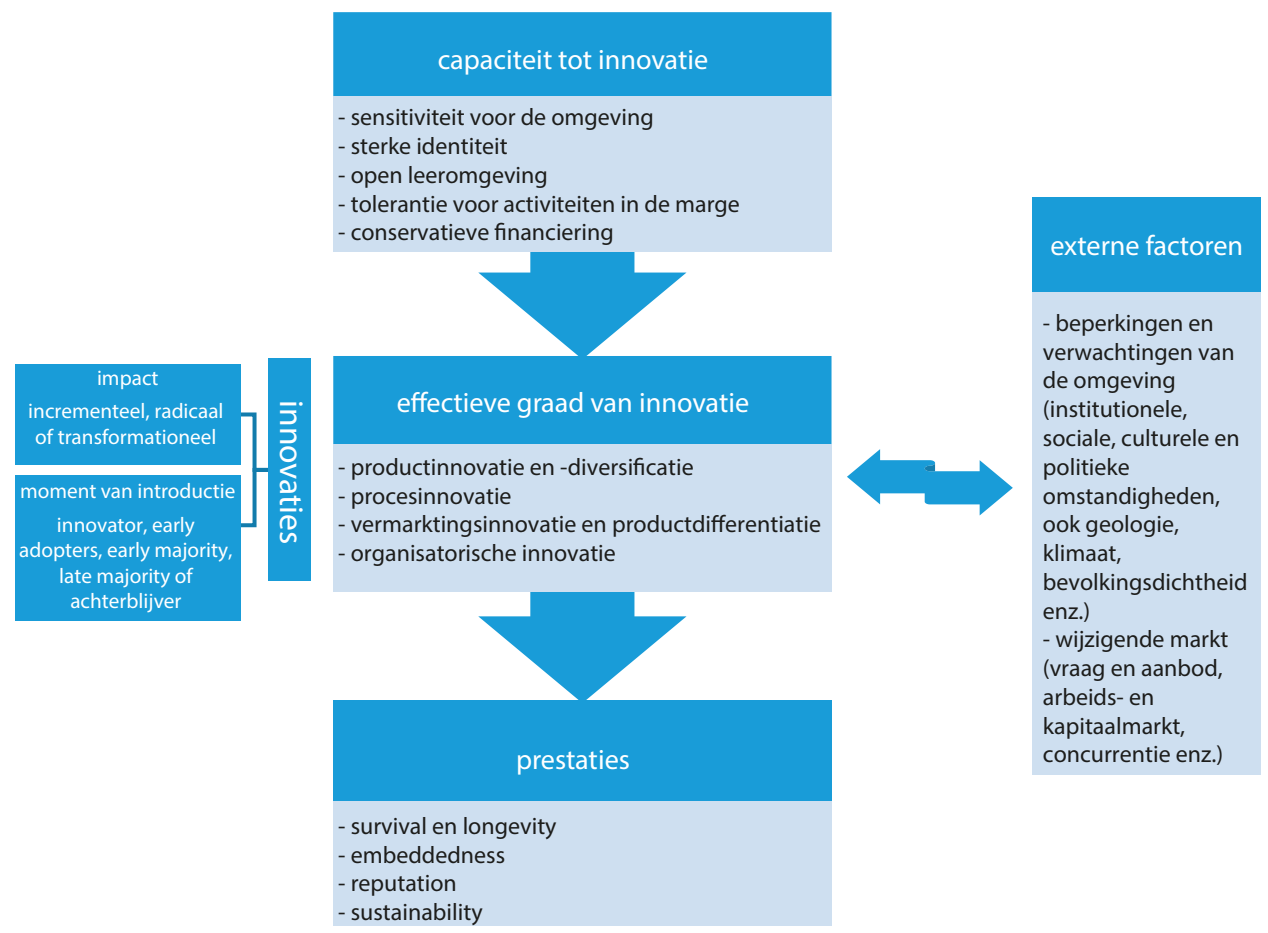

Figuur 1 Schematisch overzicht van het gehanteerde theoretische kader

Dit onderzoek poogt om de levensloop van de steen- en buizenbakkerij Dumoulin en haar performance (Colli) op bepaalde momenten in haar levensloop te verklaren vanuit de capaciteit tot innovatie (De Geus) en de effectieve graad van innovatie (Foster \& Kaplan) die het bedrijf op verschillende momenten kenmerkte. De innovatie wordt bovendien gewaardeerd (Rogers) aan de hand van de grootteorde en het ogenblik van introductie om het belang ervan voor de levensloop van het bedrijf te kunnen inschatten (zie figuur 1 voor een schematische weergave).

We stellen de hypothese voorop dat steen- en buizenbakkerij Dumoulin in periodes waarin het bedrijf een hogere capaciteit tot innovatie bezat ook daadwerkelijk een hogere graad van innovatie kende, daardoor beter in staat was in te spelen op de externe factoren, en daarmee betere prestaties wist te realiseren. Omgekeerd verwachten we in een periode waarin de prestaties tegenvallen, een lagere capaciteit tot innovatie en een lagere graad van effectieve innovatie vast te stellen. Op basis van dit kader en als gevolg van een gebrek aan kwantitatieve gegevens kunnen performance en innovatiegraad echter niet in absolute 
termen uitgedrukt worden: enkel een relatieve waardering ten opzichte van andere perioden in de levensloop van het bedrijf is mogelijk.

\section{Methodologie en bronnen}

Liberas deed in 2018-2019 binnen het kader van het project 'Dichter bij de mensen' van $\mathrm{CO}_{7}$, het samenwerkingsverband voor cultuur en erfgoed tussen de zeven gemeenten van de Zuidelijke Westhoek, in samenwerking met het Raymond Lemaire International Center for Conservation-KU Leuven (verder RLICC) en ETWIE, het Expertisecentrum voor Technisch, Wetenschappelijk en Industrieel Erfgoed, onderzoek naar de bedrijfsgeschiedenis van steen- en buizenbakkerij Dumoulin. ${ }^{15}$

Omdat er van het archief van steen- en buizenbakkerij Dumoulin slechts fragmenten bewaard zijn gebleven, bleek het noodzakelijk om verschillende onderzoeksmethodes te combineren. Hierbij werd uitgegaan van de methodologische en multidisciplinaire onderzoeksmethode van de industriële archeologie. Dit omvat een combinatie van klassiek historisch onderzoek en veldwerk. In eerste instantie werden gesprekken gevoerd met betrokkenen om een algemeen zicht te krijgen op de historiek van het bedrijf. Vervolgens werden voornamelijk historische kranten en schriftelijke bronnen uit overheidsarchieven samengebracht, waaronder dossiers hinderlijke inrichtingen, dossiers uit het kadaster, een oorlogsschadedossier (1944-1955) en handels- en nijverheidstellingen. Om meer diepgaande informatie over het bedrijf te verzamelen werd dit verder aangevuld met een analyse van historisch beeldmateriaal (uit privéarchief en via de beeldbank Westhoek verbeeldt), mondelinge geschiedenis, en architectuur- en technisch-historisch onderzoek naar de gebouwen en machines op de bedrijfssite in Wijtschate. Waar mogelijk werden alle bronnen onderling getoetst op hun betrouwbaarheid.

Voor het project mondelinge geschiedenis ${ }^{16}$ werden vanuit de centrale onderzoeksvraag acht thema's afgebakend die in de interviews aan bod moesten komen, namelijk het productieproces, de site, de organisatie, de bedrijfsleiding, de producten, de vermarkting, de omgeving en de sluiting van het bedrijf. Voor elk thema werden vragen uitgewerkt als

15 Graag danken we Delphine Vanoverberghe $\left(\mathrm{CO}_{7}\right)$, Joeri Januarius en Robin Debo (ETWIE) voor de aangename samenwerking.

16 Voor de mondelinge bronnen danken we de respondenten en de vrijwilligers, waaronder Louis Quartier, evenals Nancy Criel, medewerker van Liberas, die de transcripties deed. 
leidraad voor de interviewers, zodat de interviews enigszins uniform en vergelijkbaar zouden zijn. Er werden uiteindelijk zeven mensen geïnterviewd, namelijk Koenraad Dumoulin, kleinkind van de oprichter van het bedrijf, Jan Dumoulin, zoon van de oprichter, voormalige werknemers Roland Debeuf en César Callewaert, en kinderen van voormalige werknemers Josiane en William Callewaert (kinderen van André Callewaert), en Jean-Marie Callewaert (zoon van Roger Callewaert). Door de opzet van het project lag het zwaartepunt van de respondenten in Wijtschate. Het aantal respondenten was echter beperkt en hoorde bovendien tot een nog beperkter aantal families, namelijk familieleden van de voormalige bedrijfsleider en (familie van) drie voormalige werknemers. Dit kwam doordat veel betrokkenen (ondernemer en werknemers) al overleden waren of een hoge leeftijd hadden en omdat het moeilijk bleek om betrokkenen te lokaliseren. Door het beperkt aantal interviews kunnen deze een vertekend beeld geven. Daar staat tegenover dat naar heel wat objectieve zaken geïnformeerd werd, die getoetst konden worden aan andere bronnen en dat door de vooraf afgebakende thema's en richtvragen de interviews gemakkelijk onderling vergeleken konden worden.

Het architectuur- en technisch-historisch onderzoek gebeurde door de studenten van het RLICC met behulp van een aantal technieken van de architectuur- en ingenieurswetenschappen, waaronder fotografie, drone-opnames en opmetingen. Op basis van de scans werden visualisaties gemaakt van de inplanting, het vuilnisstort in de achterliggende kleiput, het productieproces, de omgevingsfactoren enzovoort. Daarnaast werd een inventaris opgemaakt van de aanwezige producten en productiemiddelen. ${ }^{17}$

Steen- en buizenbakkerij Dumoulin was een zogenaamd natuurlijke persoon, waardoor er slechts minimale boekhoudkundige verplichtingen waren. Het eigen bedrijfsarchief werd niet bewaard en er dienden geen balansen, jaarrekeningen en dergelijke neergelegd te worden bij een publieke instantie. Bijgevolg zijn er helaas geen kwantitatieve data beschikbaar om de analyse op te baseren.

Op basis van het bronnenonderzoek werd een reconstructie van de levensloop van het bedrijf gemaakt. Vervolgens werd deze levensloop op basis van de veranderende context waarin het bedrijf actief was en

17 Dit onderzoek werd uitgevoerd door Fatmagul Oge, Laurens Vandewyngaerde, Shlomit Raviv en Vasileios Papadoulis onder leiding van prof. dr Barbara Van der Wee, binnen het kader van hun opleiding aan het RLICC-KU Leuven. Zie: F. Oge e.a., Dumoulin. IPW III Project: Pipe and brick factory Wijtschate (Leuven 2019). 
op basis van de ontwikkelingen binnen het bedrijf zelf, onderverdeeld in een aantal periodes. Deze periodes werden ten slotte systematisch getoetst aan het theoretische raamwerk zodat de capaciteit tot innovatie, de effectieve graad van innovatie en de prestaties voor de verschillende periodes met elkaar vergeleken konden worden. Hoewel de analyse steeds dezelfde elementen onderzocht, komen deze niet allemaal in elke periode naar voren in het artikel omdat ze ofwel niet van toepassing zijn voor elke periode of om niet in herhaling te vallen.

\section{De beginjaren van steen- en buizenbakkerij Dumoulin: een steenbakkerij in Langemark (1922-1926)}

Het kader van De Geus laat ons toe om diverse externe factoren te identificeren die een impact hadden op het ontstaan en de levensloop van het bedrijf. Eén van deze factoren is de plaatselijke geografie. In de zandleemstreek in de zuidelijke Westhoek komt de kleilaag van het Ieperiaan aan de oppervlakte. Deze klei wordt gekenmerkt door een hoge plasticiteit en levert een waterdicht product op. In de regio werd dan ook heel wat klei ontgonnen voor de productie van bakstenen en drainagebuizen. Kortrijk was, naast Boom, rond het begin van de twintigste eeuw uitgegroeid tot de belangrijkste producent van dakpannen. ${ }^{18}$ Een andere externe factor die gunstige voorwaarden schiep voor het ontstaan van steen- en buizenbakkerij Dumoulin was de nasleep van de Eerste Wereldoorlog, die in de Westhoek, waar een deel van de frontlijn liep, een ware ravage aanrichtte. Dorpen en steden werden totaal vernield. Vanaf eind 1919 werd voorzichtig met de wederopbouw begonnen. Daarvoor was er een grote nood aan bouwmaterialen: bakstenen en dakpannen, maar ook drainagebuizen. Die maakten de verwoeste gronden weer bruikbaar voor de landbouw en waren ook nodig in de stallenbouw. Nadat het ergste puin geruimd was en de wegen weer enigszins berijdbaar waren, werden voormalige steenbakkerijen heropgericht en nieuwe gevestigd. Onder andere de stenen- en pannenbakkerij van Eduard Dupont in Poperinge kende een grote bloei. De context van de wederopbouw na de Eerste Wereldoorlog bood ook kansen aan nieuwe ondernemers. Een van de mensen die de mogelijkheden voor

18 R. Ottenburgs, 'Keramische delfstoffen. Fysische eigenschappen van kleigrondstoffen', in: F. Gullentops en L. Wouters (red.), Delfstoffen in Vlaanderen (Brussel 1996) 34-35, 34; W. De Breuck, 'De Eocene kleien. De Ieperiaan-kleien', in:Ibid., 36-38; N. Vandenberghe, 'De Oligocene kleien. De Boom klei', in: Ibid., 40-43, 40; J. Cornilly, 'Kortrijkse dakpannen', In de Steigers 17:3 (2010) 71-74, 72. 


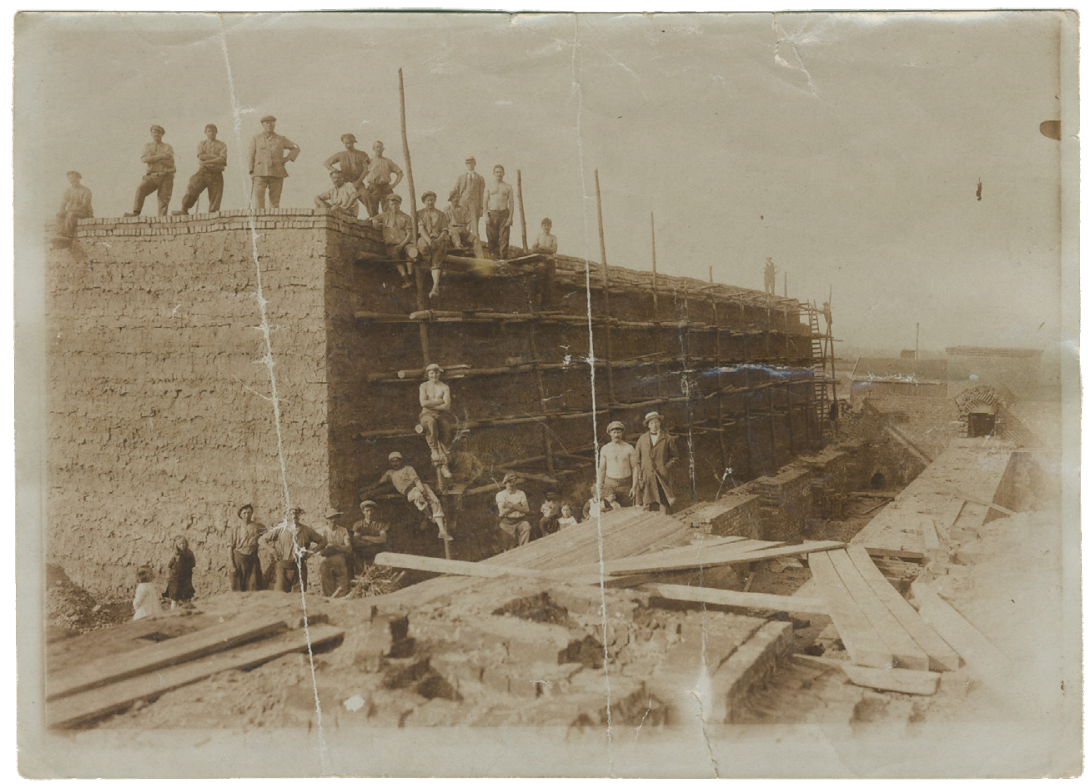

Illustratie 1 De eerste veldovens van het bedrijf in Langemark, 1922 (bron: privé-archief Koenraad Dumoulin.)

nieuwe steenbakkerijen in de streek aanvoelden, was Joseph Dumoulin (1895-1981). Hij richtte in 1922 een steenbakkerij op in Langemark. ${ }^{19}$ In tegenstelling tot de Kortrijkse bedrijven, die zich in die periode verenigden om zich sterker op de internationale markt te positioneren, ${ }^{20}$ was het bedrijf van Dumoulin een persoonlijk initiatief.

In eerste instantie liet Joseph Dumoulin grootschalige veldovens bouwen om de stenen te bakken. Dit was een achterhaalde en weinig efficiënte productiemethode, maar de enige mogelijke in het verwoeste gebied. De Duitse bezetter had de productiemiddelen immers systematisch ontmanteld en naar Duitsland geëxporteerd, waardoor de mechanisering van de industrie in West-Vlaanderen opnieuw opgebouwd

19 M. Vansuyt, 'Heuvelland in de verwoeste gewesten. De heropbouw van Wijtschate na '14-'18', in: K. Baert e.a. (red.), Histories van Heuvelland. Bijdragen ter herinnering aan Hubert Masquelin (Heuvelland 2011 ) 209-225, 211 ; Cornilly, 'Kortrijkse dakpannen', 71 ; Privé-archief Koenraad Dumoulin (hierna PA D), map 2, getuigenis van Maria Muyssen, november 1946, 4-6; Provinciaal Archief West-Vlaanderen (hierna PA WVl), Vergunningsdossiers voor gevaarlijke, hinderlijke en ongezonde bedrijven (hierna VG), A/1940-heden/A.3.-G.B./1998/P.B./6ohh; Privé-archief Johan Beun (hierna PA B), map Dumoulin, losse notities van rondleiding op de site in Wijtschate door Joseph en Jan Dumoulin op 23 februari 1980; L. Dendooven, Dit is West-Vlaanderen, deel 3 (Brugge 1962) 2130.

20 Cornilly, 'Kortrijkse dakpannen', 72. 
moest worden. ${ }^{21}$ Volgens de familieverhalen slaagde de eerste poging van steen- en buizenbakkerij Dumoulin niet helemaal: de stenen waren onregelmatig gebakken en dus van mindere kwaliteit. Om dit euvel te verhelpen, werd een man met kennis van zaken aangetrokken uit de Rupelstreek, bekend om zijn lange geschiedenis van kleiontginning en steenbakkerijen, om als 'brander' of 'stoker' te werken. Binnen de theorie van De Geus kunnen we dit beschouwen als een voorbeeld van een open leeromgeving, één aspect van de factoren die de capaciteit tot innovatie bepalen. Deze open leeromgeving leidde tot goede resultaten: de bakstenen waren nadien wél van goede kwaliteit en er kon een kapitaal opgebouwd worden. ${ }^{22}$

Uit interviews blijkt dat Joseph Dumoulin zijn steenbakkerij met eigen middelen opstartte en pas grootschalige investeringen deed wanneer er voldoende eigen kapitaal voorhanden was. Hieruit blijkt een conservatieve financiering waarbij het bedrijf volledig op intern kapitaal steunde. Ook een conservatieve financiering draagt, volgens de theorie van De Geus, bij tot een hoge capaciteit tot innovatie. Het businessmodel van de onderneming was eenvoudig: de rechtstreekse verkoop van kwalitatieve stenen tegen een marktconforme prijs aan particulieren. Door zijn huwelijk met Maria Muyssen (1898-1985), dochter van de hoofdonderwijzer en gemeentesecretaris in Langemark, kreeg Dumoulin toegang tot de lokale gemeenschap. ${ }^{23}$ Dit droeg bij aan zijn sensitiviteit voor de omgeving, wat de capaciteit tot innovatie van het bedrijf eveneens bevorderde.

Toen hij voldoende financiële middelen vergaard had met de productie van stenen in veldovens, verving Joseph Dumoulin in 1923 de veldovens door een permanente steenbakkerij. De locatie was goed gekozen, want gelegen vlak naast Spoorlijn 63 die Ieper met Oostende verbond. De uitbouw van het water- en spoorwegennet in België had het mogelijk gemaakt om vrij gemakkelijk grote hoeveelheden steenkool voor de industrie te transporteren. ${ }^{24}$ Deze steenkool was onontbeerlijk voor de steenbakkerij.

21 A. Linters, 'West-Vlaanderen, een geval apart', in: J. Vannieuwenhuyse (red.), Goed garen gesponnen? Industrialisatie in de provincie West-Vlaanderen, $1800-1940$ (Brugge 1998) 11-16, 14; A. Linters en C. Roose, 'Van landbouw naar industrie', in: Ibid., 41-69, 57; Demasure, Over werk en mensen, 70.

22 Liberas (hierna LA), Archief Dichter bij de Mensen: steen- en buizenbakkerij Dumoulin (hierna DbdM), archiefnr. 1983, interview met Koenraad Dumoulin door Louis Quartier, 3 februari 2019; PA D, map 1, foto's van de 'klampen' 1922-1923.

23 LA, DbdM, interview Koenraad Dumoulin; interview met Jan Dumoulin door Kim Descheemaeker, 18 januari 2019.

24 Demasure, Overwerk en mensen, 32. 
Voor de bouw van de productie-eenheid werd heel wat recuperatiemateriaal uit de Eerste Wereldoorlog gebruikt. ${ }^{25}$ De permanente steenbakkerij werd daarnaast ook voorzien van een aantal nieuwe machines. In het vergunningsdossier werd melding gemaakt van een aandrijfmotor die een mechanische maalmachine, een transportband, een snijder en een verdeler aandreef en een benzinemotor voor het aandrijven van een zuig- en drukpomp. ${ }^{26}$ Toch bleef de productie in de steenbakkerij, net zoals rond Kortrijk - toen één van de belangrijkste regio's van de grofkeramische industrie in België ${ }^{27}$ - nog lange tijd op negentiendeeeuwse leest geschoeid. De klei werd nog steeds handmatig afgestoken en de strengpersmachine was een negentiende-eeuwse uitvinding. ${ }^{28}$

Volgens het model van De Geus blijkt er in de eerste jaren van de steenbakkerij een relatief grote capaciteit tot innovatie aanwezig te zijn geweest. Joseph Dumoulin spreidde een grote gevoeligheid voor de omgeving tentoon en stimuleerde een open leeromgeving. Het creatieve gebruik van recuperatiemateriaal uit de Eerste Wereldoorlog wijst daarnaast op een grote tolerantie voor activiteiten in de marge. Tot slot blijkt er sprake van een conservatieve financiering. De feitelijke graad van innovatie was echter beperkt. Zowel op vlak van het aangeboden product (volle bakstenen) als ten aanzien van de organisatie van het bedrijf (businessmodel en organigram) kunnen geen innovatieve strategieën ontwaard worden. Het productieproces werd enigszins gemoderniseerd door, zodra dit financieel mogelijk was, een ringoven te bouwen in plaats van verder te produceren in veldovens. Wanneer we deze vernieuwingen toetsen aan de rangschikking van Foster en Kaplan kunnen we concluderen dat dit voor het bedrijf een radicale innovatie betekende. Volgens de diffusietheorie van Rogers behoorde Dumoulin echter eerder tot de late adopters, aangezien de ringoven al sinds het midden van de negentiende eeuw een sterk verspreide productiemethode was. Nochtans bleven bepaalde bedrijfes in het Brusselse nog tot ver in de twintigste eeuw bakstenen produceren in veldovens. ${ }^{29}$

Mede dankzij gunstige externe factoren was er ondanks de beperkte effectieve graad van innovatie toch sprake van goede prestaties op de di-

25 PA D, map 1, foto's 1924.

26 PA WVl, VG, A/1940-heden/A.3.-G.B./1998/P.B./62bb.

27 N. Plevoets, 'Kleikoppen, zandputten en de relicten in het landschap', in: B. De Meulder, S. Hoornaert, K. Van Herck (red.), Metamorfosen: een ruimtelijke biografie van de regio Kortrijk (Brussel 2010) 16o-171, 167 .

28 Vereniging Koninklijke Nederlandse Bouwkeramiek (hierna KNB), Van klei tot baksteen en meer (Velp 2007) 3, 8; P. De Somer, Van klei tot baksteen (Antwerpen 1984) 38.

29 G. Peirs, Uit klei gebouwd. Baksteenarchitectuur van 1200 tot 1940 (Tielt 1979) 97-99. 
verse vlakken die Colli identificeerde: steenbakkerij Dumoulin slaagde erin de eerste moeilijke jaren van de opstart te overleven (survival) en zich te vestigen als familiale kmo (sustainability). Daarnaast raakte Joseph Dumoulin gemakkelijk ingebed in de lokale samenleving (embeddedness). Hij kon geleidelijk een economisch en sociaal kapitaal opbouwen.

\section{Het bedrijf breidt uit (1926-1940)}

In 1926 nam Joseph Dumoulin een zieltogende steen- en pannenbakkerij in Wijtschate over, wat hem toeliet om zijn productie te diversifiëren. De productie-eenheid lag dan wel in de gemeente Wijtschate maar bevond zich vlakbij het stadje Mesen. De bedrijfsafdeling specialiseerde zich in drainagebuizen en holle stenen. ${ }^{30}$ Net als in de beginjaren schatte Joseph Dumoulin de behoeften van de markt goed in. Door de productie-eenheid in Wijtschate te richten op drainagebuizen kon hij nieuwe producten aanbieden (productdiversificatie), die gretig aftrek vonden onder landbouwers. De nieuwe productie-eenheid was daarvoor ideaal gelegen: midden in landbouwgebied, vlakbij het stadje Mesen. De krant De Poperinghenaar was ervan overtuigd dat het bedrijf een lang leven beschoren was omdat, hoewel de vraag naar stenen sterk afnam, de productie van de draineerbuizen erg kwaliteitsvol was. ${ }^{31}$ In de jaren 1930 werd de dakpannensector geconfronteerd met toenemende concurrentie uit Nederland en een afname van de export. ${ }^{32}$ Doordat Dumoulin zich op de lokale markt richtte en andere grofkeramische producten dan dakpannen produceerde, ondervond hij hier geen gevolgen van.

Net als in de steenbakkerij in Langemark was ook het productieproces in de buizenbakkerij in Wijtschate weinig vernieuwend, hoewel Dumoulin een smalspoor liet aanleggen voor het transport van de klei uit de putten, en een meng- en kneedmachine en een strengpersmachine introduceerde. Bovendien liet hij de oven van de buizenbakkerij verhogen waardoor er bovenop de oven een verdieping beschikbaar werd om de vormelingen te laten drogen. ${ }^{33}$ Door de warmte uit de oven verliep dit sneller dan in aparte droogloodsen. Dit idee werd in de jaren twin-

30 Dendooven, Dit is West-Vlaanderen, 2130.

31 'Langemarck - Onze nijverheid', De Poperinghenaar 23 mei (1926) 2.

32 Cornilly, 'Kortrijkse dakpannen', 73.

33 Gesprek van de auteur met Koenraad Dumoulin, Ieper, 5 oktober 2018; LA, DbdM, interview met Jan Dumoulin; PA D, map 1, foto's van de oven 1926-1932; Westhoek verbeeldt (hierna WV), Privé-archief (hierna PA), fotonr. HEUoo5503396. 
tig in verschillende steen- en buizenbakkerijen uitgeprobeerd maar deze incrementele procesinnovatie bleek uiteindelijk toch weinig rendabel. ${ }^{34}$ Omwille van de beperkte capaciteit van deze droogplaats liet Dumoulin enkele losstaande droogloodsen bijbouwen. Het is opmerkelijk dat onder meer twee droogloodsen van elk vier verdiepingen gebouwd werden; constructies die niet bij andere steenbakkerijen aangewend werden. De droogoppervlakte werd zo vergroot, maar het werk werd enigszins bemoeilijkt omdat de buizen tot de bovenste verdieping gebracht moesten worden. Een liftsysteem bracht soelaas. ${ }^{35}$

Joseph Dumoulin probeerde in deze periode veel innovaties uit. Zowel in Langemark als in Wijtschate werden de stenen en buizen gebakken in een ringoven. Een stoker hield het vuur in de oven brandende door kolen toe te voegen langs openingen in het plafond. Aanvankelijk moesten de stokers steeds kleine en precies gedoseerde hoeveelheden steenkool toevoegen langs de kokers, maar Joseph Dumoulin installeerde een innovatief systeem met trechters. Een stoker zorgde dat de trechtermonden boven de oven steeds voorzien waren van kolen, waarna de steenkool door de verbinding van de trechters met een timer of klok gedoseerd door de kokers viel. Het stoken werd zo deels geautomatiseerd. ${ }^{36}$ In navolging van Foster en Kaplan kunnen we dit beschouwen als een incrementele innovatie die het werk van de stokers verlichtte.

Het werk in de steen- en buizenbakkerij was seizoensgebonden. Het bedrijf beschikte niet over een kleischuur om de klei op te slaan, waardoor deze in de winter bevroor en niet bewerkbaar was. De vormelingen konden in de winter bovendien niet goed drogen. In het zomerseizoen, ongeveer van Pasen tot oktober, wonnen de kleistekers de klei en werden de stenen en buizen gebakken; in de winter lag de productie volledig stil, maar werd er wel geleverd en werden er herstellingen uitgevoerd. Slechts enkele werknemers bleven tijdens de winter aan de slag. De anderen waren tijdelijk werkloos of werkten als seizoenarbeider in Frankrijk. ${ }^{37}$

34 P. De Niel, Gevormd, gedroogd en voor de eeuwigheid gebakken (Boom 200o) 19; Peirs, Uit klei gebouwd, 99 .

35 LA, DbdM, interview met Jan Dumoulin; PA D, map 1, foto's van de oven 1926-1932; WV, Privé-archief (hierna PA), fotonr. HEUoo5503396.

36 LA, DbdM, interview met Roland Debeuf door Delphine Vanoverberghe, 31 januari 2019; interview met Koenraad Dumoulin; WV, PA, fotonr. HEUoo5503424; PA D, map 1, foto's van de uitvinding; brevet d'invention, 31 december 1935 .

37 LA, DbdM, interview met Jan Dumoulin; interview met Koenraad Dumoulin; interview met Roland Debeuf; interview met César Callewaert door Brigitte Stevens en Louis Quartier, 30 januari 2019; interview met Jean-Marie Callewaert door Kim Descheemaeker, 9 mei 2019; interview met William Callewaert door Louis Quartier, 24 maart 2019. 

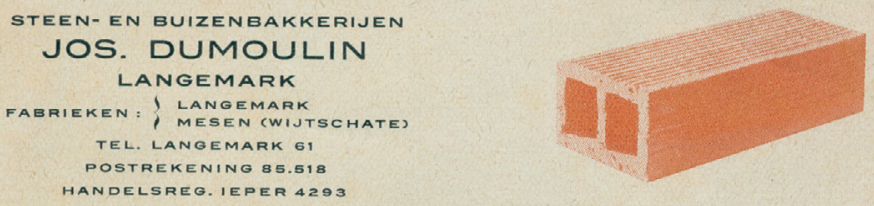

\section{Snelbouwsteen}

Afmetingen: $30 \times 14 \times 9 \mathrm{~cm}$.

Aard der stof : gebakken aarde.

Kleur: licht-rood.

30 stuks per $\mathrm{m}^{2}$ plat gewerkt.

21 stuks per $\mathrm{m}^{2}$ op kant gewerkt.

Verwerken even rap en goedkoop als as-stenen en passen om met de gewone baksteen samen te werken voor het maken van hoeken en neggen.

Hierna de uitslag der proeven gedaan op het laboratorium voor proeven der Universiteit van Leuven :

1) Poreusheid (vochtopname): $10,78 \%$

2) Bevriezingsproef : $100 \%$ voldoening.

3) Drukproef : $36,08 \mathrm{~kg}$. per $\mathrm{cm}^{2}$.

Illustratie 2 Reclamefolder voor de snelbouwstenen die geproduceerd werden op de site in Wijtschate, datum onbekend (bron: privé-archief Koenraad Dumoulin.) 
In 1937 waren er 161 inrichtingen in West-Vlaanderen werkzaam in de aardewerkindustrie en aanverwante branches. Zij stelden samen 3.171 mensen tewerk, waarvan 3.116 mannen en 55 vrouwen. Hiermee was de sector slechts een relatief kleine werkgever in de provincie. In het arrondissement Ieper - waartoe Langemark en Wijtschate behoorden - lag het zwaartepunt van de aardewerkindustrie in de gemeentes Komen, Ieper, Poperinge en Watou. In het arrondissement waren in totaal 23 bedrijven in de sector actief, waarvan er dertien door een natuurlijk persoon werden uitgebaat. Dumoulin behoorde tot de grotere bedrijven. Slechts zeven bedrijven stelden immers meer dan tien werklieden tewerk, terwijl in steen- en buizenbakkerij Dumoulin op elke bedrijfssite een twintigtal arbeiders werkten. Ten opzichte van het arrondissement Kortrijk was dit echter vrij klein. Daar waren immers 46 bedrijven actief, waarvan zestien met meer dan tien werklieden en waarvan er zelfs vijf meer dan honderd mensen in dienst hadden. Ook daar was het gros van de bedrijven nog in handen van de eigenaar, en niet ondergebracht in een vennootschapsvorm..$^{38}$

Het loon bij de firma Dumoulin lag volgens een krantenartikel hoger dan in enkele andere steenbakkerijen in de streek. ${ }^{39}$ We beschikken niet over concrete informatie over de verloning bij steen- en buizenbakkerij Dumoulin, maar uit de nijverheidstelling van 1947 blijkt dat 67 procent van de mannelijke arbeiders in de sector toen tussen de 15 en 25 Belgische frank per uur verdiende. De specifieke verloning was afhankelijk van de ervaring en van het werk van de arbeider. ${ }^{40}$ Bij steen- en buizenbakkerij Dumoulin werden de meeste arbeiders niet per uur maar per honderd geproduceerde stenen betaald. De stokers ontvingen wel een uurloon.

De familie Dumoulin voerde met financiële steun en liefdadigheid een patronale sociale politiek die de arbeiders nog sterker aan het bedrijf bond. Vooral Maria Muyssen stond bekend om haar stille steun en liefdadigheid aan de armlastigen onder de werknemers en de bredere Langemarkse bevolking. ${ }^{41}$ Dit leidde tot een sterke identiteit en betrokkenheid van het personeel, waardoor zij jaarlijks na de winterstop bijna

38 Economische en sociale telling van 27 februari 1937. Telling van de handels- en nijverheidsinrichtingen Provincie West-Vlaanderen (Brussel 1937) 4-5, 9, 42, 50-51.

39 J. Clement, 'Rond de staking in de brijkerij M. Sady Schaballie, te Poperinge', De Halle 15 augustus (1937) 6 .

40 Algemene Volks-, Nijverheids- en Handelstelling op 31 december 1947, vol. XI Lonen in de Nijverheid (Brussel 1953) 12-15, 22-23.

41 G. Vandromme, 200 jaar burgemeesters in Langemark-Poelkapelle (Langemark-Poelkapelle 2015) 81 . 
voltallig opnieuw aan de slag gingen bij de steen- en buizenbakkerij. ${ }^{42}$ Een dergelijke sterke identiteit draagt volgens De Geus bij aan een grotere capaciteit tot innovatie.

Rond 1900 vonden de eerste vormen van prefabricage in het bouwproces plaats. Vanaf 1907 kwamen bijvoorbeeld bakstenen welfsels op de markt. Maar vooral tijdens het interbellum kenden dergelijke nieuwigheden een brede verspreiding. ${ }^{43}$ Joseph Dumoulin speelde in op de vraag van de bouwsector en introduceerde enkele nieuwe producten. In Wijtschate vormden holle stenen, als voorlopers van de snelbouwstenen, een voorbeeld van productinnovatie en -diversificatie. ${ }^{44}$ Bepaalde types holle stenen konden gebruikt worden als vloerbekleding in varkensstallen omdat ze een isolerende werking hadden. ${ }^{45}$ Later werden bepaalde holle stenen ook onder de naam 'snelbouwstenen' verkocht. In een advertentie werd op de kwaliteit van de stenen gewezen aan de hand van de resultaten van proefnemingen door onderzoekers van de Katholieke Universiteit Leuven. ${ }^{4}$ De advertenties en de bewaarde rekeningen tonen aan dat er vooral in de eigen regio verkocht werd, hoewel er leveringen tot aan de kust plaatsvonden. Zowel particulieren als ondernemers kochten bakstenen bij de steen- en buizenbakkerij Dumoulin. ${ }^{47}$

Op het einde van de jaren 1930 gingen de zogenaamde 'Meesenbalken', prefab welfsels met bewapening, in productie. Wanneer we dit toetsten aan de diffusietheorie van Rogers, kunnen we stellen dat Dumoulin met de introductie van dit product wellicht tot de early majority behoorde. De welfsels bestonden uit vier rijen balken van op elkaar gemetselde holle stenen met ertussen ijzeren staven. De Meesenbalken bleven in productie tot in de jaren 1970. In een folder werd gewezen op de lichtheid, de onbrandbaarheid en de temperatuur- en geluidsisolatie van de balken. Bovendien waren ze condensatiewerend en stonden ze garant voor scheurvrije plafonds. Er kon gemakkelijk en snel mee gebouwd worden. Deze radicale productinnovatie had een grote impact op de bedrijfsvoering. De welfsels werden op bestelling gemaakt, ze waren erg populair en verkochten heel goed. Ze vormden het parade-

\footnotetext{
42 LA, DbdM, interview Jan Dumoulin; interview Koenraad Dumoulin; interview Roland Debeuf; interview César Callewaert.

43 KNB, Van kleitot baksteen en meer, 3; Peirs, Uit kleigebouwd, 143.

44 Gesprek van de auteur met Koenraad Dumoulin, Ieper, 5 oktober 2018.

45 PA B, map Dumoulin, losse notities.

46 PA D, map 1, advertentie snelbouwstenen.

47 LA, DbdM, interview Roland Debeuf; interview Jan Dumoulin; interview William Callewaert; PA D, map 3, rekeningen en advertenties.
} 
paardje van steen- en buizenbakkerij Dumoulin. ${ }^{48}$ Het bedrijf wist zo een concurrentieel voordeel te verwerven en een duidelijke positie in te nemen op de markt. In deze periode werd daarnaast sterk ingezet op de vermarkting. Niet enkel advertenties in kranten maar ook folders werden gebruikt om de producten een grotere zichtbaarheid te geven.

Op basis van de theorie van De Geus kunnen we ook in deze periode veranderende externe factoren identificeren: zo was de lokale markt gunstig voor drainagebuizen, terwijl de vraag naar bakstenen afgenomen zou zijn. Daar staat tegenover dat er vanuit de bouwsector vraag kwam naar nieuwe producten. Door zijn sensitiviteit voor de omgeving, de sterke identiteit van het bedrijf, de blijvende conservatieve financiering en de tolerantie voor activiteiten in de marge, kon steen- en buizenbakkerij Dumoulin diverse strategieën aanwenden om op de veranderende markt te reageren. Met de snelbouwstenen en prefabwelfsels werd ingezet op productinnovatie en -diversificatie. Deze vernieuwingen kunnen we in navolging van Foster en Kaplan beschouwen als radicale innovaties, en volgens het model van Rogers waarderen als geïntroduceerd door een early majority. De vermarktingsinnovatie lijkt eerder een incrementele innovatie door een late majority te zijn geweest. In het productieproces werden enkele incrementele innovaties uitgeprobeerd, waarvan vooral de kolentrechters succesvol bleken. Hoewel Dumoulin voor dit laatste op basis van zijn uitvindersbrevet als innovator beschouwd zou kunnen worden, moet deze waardering toch met de nodige omzichtigheid benaderd worden.

De diverse bedrijfsstrategieën uitten zich in goede prestaties, op de diverse vlakken die Colli identificeerde: het bedrijf kon uitbreiden en als familiebedrijf blijven bestaan (survival en longevity), kende een sociale verankering door haar patronale sociale politiek (embededdness) en kreeg de reputatie een goede werkgever te zijn die kwaliteitsvolle producten leverde (reputation). De familie Dumoulin kon in deze periode haar economisch en sociaal kapitaal verder uitbouwen en versterken (sustainability).

48 PA D, map 1, advertentiefolder Meesenbalken; LA, DbdM, interview Roland Debeuf; interview Koenraad Dumoulin; interview Jan Dumoulin. 


\section{De Tweede Wereldoorlog versterkt het sociaal kapitaal (1940-1944)}

Onder het dreigende oorlogsgeweld adverteerde Joseph Dumoulin in 1939 voor een 'familieschuilplaats voor 8 personen met beschutte ingang en nooduitgang tegen luchtdruk, bomscherven, val van materialen'. Voor de prijs van 1.6oo frank werd de schuilplaats binnen een omtrek van tien kilometer van de fabriek in Langemark geleverd en geplaatst. ${ }^{49}$ Het valt op dat de advertentie niet het bedrijf in zijn geheel aanprijst maar een specifiek product in het licht stelt. Hoewel het nieuwe product een radicale innovatie was en Dumoulin het op de markt bracht als innovator, was de verkoop ervan sterk afhankelijk van bepaalde sentimenten onder de bevolking en van de oorlogsomstandigheden, en lijkt het weinig impact te hebben gehad op het bedrijf.

De meidagen van 1940 veroorzaakten schade aan de bedrijfsterreinen in Langemark en Wijtschate. In Wijtschate hadden Engelse en Franse soldaten zich ingegraven rond de steenbakkerij. Het Duitse leger schoot met scherp op deze schuilplaatsen. Bij de herstellingen later dat jaar telde Joseph Dumoulin niet minder dan twintig schuilputten en negen obuskraters. Ook in Langemark maakten de troepen gebruik van de mogelijkheden die de steenbakkerij bood. De rieten matten werden gebruikt om wagens te verbergen of om op te slapen. Bakstenen en poutrellen deden dienst om over grachten te rijden. Niet minder dan 2.0oo buizen, 2.000 holle stenen, $58,4 \mathrm{~m}^{2}$ Meesenbalken, 4.700 bakstenen en $280 \mathrm{~kg}$ poutrellen raakten door het oorlogsgeweld beschadigd. Dit was slechts het topje van de ijsberg want niet enkel afgewerkte producten, klaar voor verkoop, maar ook allerlei bedrijfsmateriaal werd vervreemd of vernield. ${ }^{\circ}$

Joseph Dumoulin en Maria Muyssen toonden zich ook in de woelige jaren van de Tweede Wereldoorlog gevoelig voor hun omgeving. Hoewel het Comité Galopin zich na de Belgische capitulatie uitsprak voor een algemene werkhervatting om de deportatie van arbeiders en de ontmanteling van machines te voorkomen, ${ }^{51}$ volgden de Dumoulins deze strategie slechts gedeeltelijk. De steenbakkerij in Langemark bleef gedurende de hele oorlog gesloten omdat werken voor de bezetter in de

\footnotetext{
49 'Tegen luchtaanvallen', De Halle 22 oktober (1939) 4; 29 oktober (1939) 4; 5 november (1939) 4; 'Tegen luchtaanvallen', De Poperinghenaar 22 oktober (1939) 4.

$5^{\circ}$ Rijksarchief van de Provinciën in Brugge (hierna RA B), Oorlogsschadedossiers (hierna O), nr. 3.003.111.

51 Demasure, Over werk en mensen, 71.
} 
streek erg negatief bekeken werd. De buizenbakkerij in Wijtschate bleef wel verder produceren om de arbeiders werk te verschaffen en om een inkomen te genereren voor de familie. Ook arbeiders van de site in Langemark werden tijdelijk tewerkgesteld op de productie-eenheid in Wijtschate. De drainagebuizen werden voornamelijk aan plaatselijke landbouwers geleverd, dus beschouwde de familie Dumoulin dit niet als collaboratie. Bovendien zette de familie haar sociaal beleid verder door brandstof en voedsel uit te delen aan wie dat nodig had. ${ }^{52}$ Kort na de bevrijding bleek echter dat niet iedereen dit zo ervaren had. Sommigen beschuldigden de familie Dumoulin ervan wel degelijk gecollaboreerd te hebben. De werknemers voelden zich echter sterk met het bedrijf en de familie verbonden. Zij ontkenden de beschuldigingen ten stelligste en maakten het zo onrechtstreeks mogelijk dat Joseph Dumoulin in 1946 verkozen werd als burgemeester van Langemark..$^{53}$

Dumoulin wist creatief om te springen met de mogelijkheden en moeilijkheden die de omstandigheden boden. Omwille van een gebrek aan brandstof werden de vrachtwagentjes die gebruikt werden om de klei en de gebakken stenen en buizen te vervoeren, omgebouwd om op gas te kunnen rijden. ${ }^{54}$ De tolerantie voor dergelijke activiteiten in de marge leidde tot een aanpassing van de productiemiddelen en dus een beperkte procesinnovatie. Het lijkt erop dat Joseph Dumoulin met deze incrementele innovatie een innovator was, maar hij commercialiseerde zijn uitvinding nooit en gebruikte het enkel in functie van de kernactiviteiten van de steen- en buizenbakkerij. De conservatieve financiering van het bedrijf bleef in deze periode overeind. Dat het bedrijf volledig op intern kapitaal berustte, wordt bevestigd door het oorlogsschadedossier. In dat dossier wordt de familie Dumoulin in vermogenscategorie E geplaatst, wat wil zeggen dat hun vermogen zich op 9 oktober 1944 tussen twee en vijf miljoen frank bevond. ${ }^{55}$ Dit vermogen bestond waarschijnlijk voornamelijk uit onroerende goederen zoals de bedrijfsgebouwen en -gronden.

In 1947 stond niet minder dan $5^{6}$ procent van de bedrijven in de sector van de niet-metaalhoudende mineralen nog steeds op persoonlijke naam. Hoewel er een tendens was ten voordele van het oprichten

52 Vandromme, 200jaar burgemeesters, 80.

53 WV, PA, fotonr. HEUoo5503408; fotonr. HEUoo5506665; LA, DbdM, interview César Callewaert; interview Koenraad Dumoulin; PA D, map 2, getuigenis Maria Muyssen, 9.

54 WV, PA, fotonr. HEUoo5502955; PA D, uitvindersbrevetten 1940 en 1941.

55 RA B, O, nr. 3.003.111. 


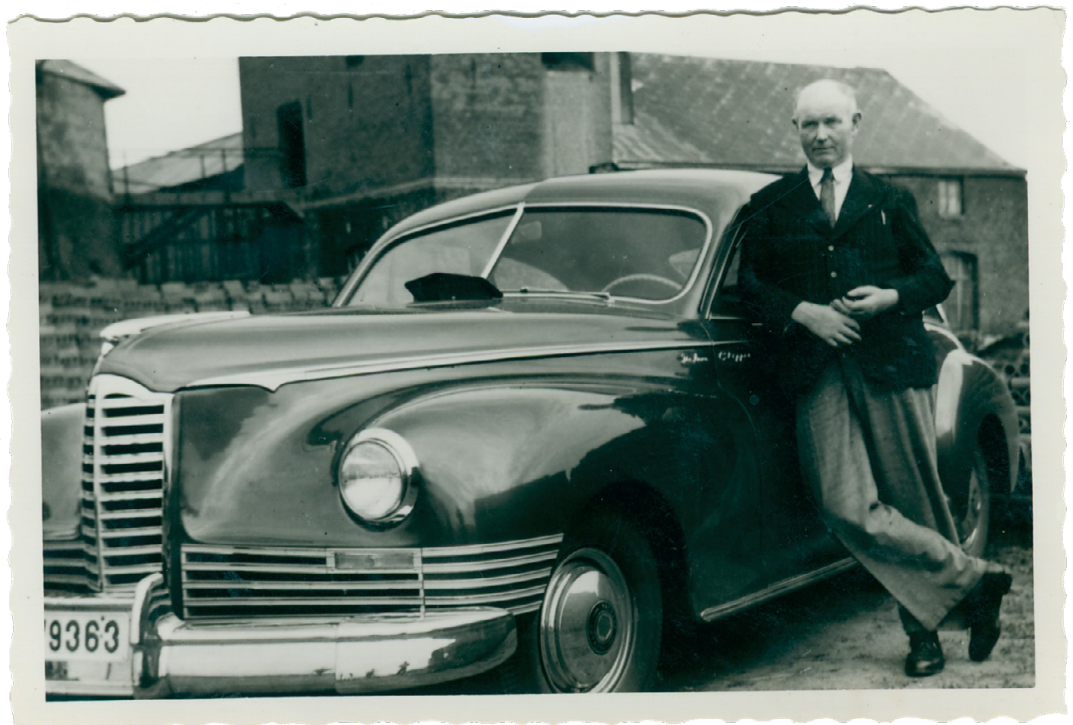

Illustratie 3 Bedrijfsleider Joseph Dumoulin poseert bij zijn auto aan de buizenbakkerij in Wijtschate, ca. 1946 (bron: privé-archief Koenraad Dumoulin.)

van vennootschappen bleven heel wat bedrijven éénmanszaken. ${ }^{56}$ Vennootschappen boden nochtans voordelen om kapitaal aan te trekken en konden afhankelijk van de vennootschapsvorm leiden tot beperkte aansprakelijkheid. Bovendien is het gemakkelijker om een vennootschap na te laten dan een éénmanszaak, die automatisch ophoudt te bestaan bij het overlijden van de ondernemer. Toch verkoos ook Joseph Dumoulin om zijn bedrijf verder te zetten als persoonlijk initiatief.

De Tweede Wereldoorlog had een grote impact op de context waarbinnen steen- en buizenbakkerij Dumoulin actief was, en bij uitbreiding op de hele samenleving. Zowel op politiek als sociaal vlak veranderden de voorwaarden waarbinnen Dumoulin kon produceren. De bedrijfsleider probeerde een evenwicht te vinden tussen produceren voor de bezetter, wat sociaal moeilijk lag maar er ook voor zorgde dat alle personeelsleden konden aanblijven, en de productie stil leggen. De oplossing lag er voor hem in om enkel het bedrijf in Wijtschate draaiende te houden. Daarnaast zorgde de oorlogscontext voor schade aan de bedrijfssites en voor een gebrek aan brandstof. Hoewel binnen het bedrijf een relatief hoge capaciteit tot innovatie aanwezig was, uitte zich dat slechts heel beperkt in daadwerkelijke innovaties. Tot de schaarse 
voorbeelden behoorden het aanbieden van een schuilplaats naar aanleiding van het dreigende oorlogsgeweld en de ontwikkeling van een vrachtwagen op gas. Desondanks kon de familie Dumoulin haar sociaal kapitaal (embeddedness en reputation) toch versterken door in te spelen op de omgeving en creatieve oplossingen te bedenken. Het bedrijf kon blijven produceren en haar positie enigszins versterken (survival and longevity). Het sociale en economische kapitaal werden zo duurzaam verankerd (sustainability).

\section{Een doorstart en heropleving in de jaren $195^{\circ}$ $\left(1945^{-1960)}\right.$}

In 1946 werd Joseph Dumoulin, die voordien niet politiek actief was, verkozen als burgemeester van Langemark voor de Christelijke Volkspartij (CVP). Hij bleef aan tot $195^{8}$ en hield zo de vinger aan de pols bij de lokale gemeenschap. Zijn burgemeesterschap werd gekenmerkt door sociale bewogenheid en voeling met het verenigingsleven. Ook zijn erevoorzitterschap van de Langemarkse boldersclub droeg bij aan de sensitiviteit voor de omgeving. ${ }^{57}$ Hiermee werd ook een zakelijk belang gediend: de verkoop van de stenen en buizen bleef immers grotendeels lokaal georiënteerd. Net zoals voorheen werd voornamelijk rechtstreeks aan particulieren verkocht. De producten werden ter plaatse op de fabriek opgehaald of naar een stapelplaats in Langemark gebracht. Een deel werd nu ook via groothandelaars van bouwmaterialen verkocht..$^{5}$ In Mesen, waar de buizenbakkerij in Wijtschate vlakbij lag en waar één van de kleiputten zich bevond, bleek de verhouding met het stadsbestuur wat meer gespannen. De firma Dumoulin werd in 1948 aangemaand om financieel bij te dragen aan de herstelling van een straat omdat de schade het gevolg was van het vrachtverkeer dat klei van de verderaf gelegen kleiput naar de buizenbakkerij vervoerde. 59

Het waren echter niet langer voornamelijk de lokale omstandigheden die het bedrijf beïnvloedden, maar de evoluties op sectorale en internationale schaal. Zo zorgden infrastructuurwerken, lage lonen en de groeiende vraag naar bakstenen op de wereldmarkt vanaf het einde van de jaren 1940 voor een economische bloeiperiode van de West-Vlaamse industrie. De Westhoek bleef echter maar heel beperkt ontsloten en

57 Vandromme, 200 jaar burgemeesters, 75-82.

58 WV, PA, fotonr. HEUoo5502012; LA, DbdM, interview Roland Debeuf.

'Meesen, Gemeenteraadszitting', Het Wekelijks Nieuws 14 februari (1948) 5 . 
kende weinig industriële activiteit. ${ }^{60}$ Tegelijkertijd vond in de grofkeramische industrie een grootschalige mechanisatie en automatisering plaats, waardoor de sector een verschuiving kende van een arbeidsintensieve industrie naar een kapitaalintensieve industrie. Bij de Briquetteries et Tuileries d'Oedelem in de regio Brugge was het kleisteken in 1936 als één van de eersten vervangen door een baggermolen, ${ }^{61}$ hoewel baggermolens al sinds het einde van de negentiende eeuw bekend waren. In de loop van de jaren 1950 werden de manuele kleistekers in de hele sector definitief vervangen door mechanische kleibaggers. ${ }^{62}$ Ook steen- en buizenbakkerij Dumoulin schakelde in de jaren 1950 over op een mechanische baggermachine. Bovendien werd er elektriciteit aangelegd, wat relatief laat was; dat is echter te verklaren door de trage ontsluiting van de Westhoek. Onder het burgemeesterschap van Joseph Dumoulin werden alle afgelegen wijken en dorpen van de gemeente Langemark van elektriciteit voorzien. ${ }^{63}$ Daarnaast werden op de steenbakkerij de smalsporen vervangen door een transportband. De schoepen van de graafmachine konden zo klei en aarde scheppen, die via de transportband in een mengmachine belandden. Waar voorheen een werknemer de juiste hoeveelheid klei en aarde in de meng- en kneedmachine moest scheppen, gebeurde dat nu automatisch. Met een klep konden de verhoudingen van het mengsel aangepast worden. ${ }^{64}$ Volgens de rangschikking van Foster en Kaplan was deze gedeeltelijke automatisering en verdere mechanisering duidelijk een radicale innovatie voor het bedrijf. Zoals eerder reeds aangegeven is ook het moment van introductie van essentieel belang voor de waardering van innovaties. Binnen het model van Rogers behoorde Dumoulin op sectoraal niveau niet tot de voorhoede en was hij eerder een late adopter. Hoewel de innovatie een grote impact had op de arbeidstijd en -kosten, lijkt het dan ook geen concurrentieel voordeel te hebben opgeleverd.

6o Demasure, Overwerken mensen, 129-131. Zo werd onder meer spoorlijn 63 waarlangs de steenbakkerij in Langemark zich bevond in 1955 afgesloten voor personenverkeer en tussen Torhout en Kortemark zelfs volledig opgebroken.

61 De Niel, Gevormd, gedroogd, 22; M. De Vos en J.Vannieuwenhuyse, 'Cataloog', in:Vannieuwenhuyse (red.), Goed garen gesponnen?, 174.

62 F. Mostaert, 'Klei en maatschappij' in: Gullentops en Wouters (red.), Delfstoffen in Vlaanderen, 4849; KNB, Van klei tot baksteen en meer, 3-4; De Somer, Van klei tot baksteen, 20, 29.

63 Vandromme, 2oojaar burgemeesters, 78.

64 LA, DbdM, interview Roland Debeuf; interview William Callewaert; interview Jean-Marie Callewaert; interview Jan Dumoulin; interview Koenraad Dumoulin;WV, PA, fotonr. HEUoo5503389; fotonr. HEUoo5506627. 
Op organisatorisch vlak veranderde er in het bedrijf nauwelijks iets. De arbeidsstructuur was sterk egalitair en bleef gedurende de hele levensloop van het bedrijf gelijk. Het bedrijf werd geleid door het echtpaar Joseph Dumoulin en Maria Muyssen. Maria bleef meer op de achtergrond en nam de financiële en administratieve leiding op zich. Joseph volgde de dagelijkse bedrijfsvoering en technologische kant van de onderneming van nabij. Op beide fabrieken stond bovenaan de ladder de meestergast die de werkzaamheden aanstuurde. Onderaan de ladder stonden de beginners die als bakkenzetter en vetlapper werkten. Maar tussen alle andere functies bestond geen hiërarchie. Deze vlakke organisatiestructuur bevorderde de onderlinge contacten. De werknemers oefenden steeds dezelfde functie uit binnen de fabriek. Slechts enkelen waren polyvalent. ${ }^{65}$ Steen- en buizenbakkerij Dumoulin kon een goede band opbouwen met haar werknemers en creëerde een sterke identiteit. De arbeiders vonden dat ze steeds eerlijk naar werk betaald kregen; ook de zoons van de ondernemer deden aanvankelijk hetzelfde werk als de arbeiders, en er hing meestal een goede sfeer tussen de collega's. Als gevolg van de goede band met het personeel, telde het bedrijf meerdere leden en generaties van dezelfde families onder haar werknemers. ${ }^{66}$

Op beide bedrijfssites van steen- en buizenbakkerij Dumoulin werkten zo'n 20 tot 25 arbeiders. In de sector van de steenbakkerijen waren er in 1947 in heel België 429 inrichtingen met bezoldigd personeel. In West-Vlaanderen waren 64 pannen- en steenbakkerijen gevestigd. Daarvan stelden er 39 minder dan 20 personeelsleden tewerk, veertien tussen de 20 en 49 personeelsleden, en elf tussen de 50 en 500 . Steenbakkerij Dumoulin behoorde dus tot de middelgrote bedrijven. ${ }^{67}$ De meeste personeelsleden van steen- en buizenbakkerij Dumoulin woonden vlakbij de bedrijfssite waar ze werkten. Ze gingen te voet of met de fiets naar het werk.

Van de tewerkgestelden in steen- en pannenbakkerijen was het merendeel man, slechts zo'n 3 procent was vrouwelijk. Bij meer verfijndere keramische producten, zoals de vloertegels en mozaïeken lag dat percentage hoger ${ }^{68}$ Het is dan ook niet uitzonderlijk dat ook bij steen- en buizenbakkerij Dumoulin nauwelijks vrouwen tewerkgesteld waren,

65 LA, DbdM, interview Roland Debeuf; interview Jan Dumoulin.

66 LA, DbdM, interview Jean-Marie Callewaert; interview William Callewaert; interview Cesar Callewaert; interview Roland Debeurf; interview Jan Dumoulin; WV, PA, fotonr. HEUoo550667; HEUoo5503017; HEUoo5503388; HEUoo5503401; HEUoo5502765.

67 Algemene Volks-, Nijverheids- en Handelstelling op 31 december 1947, 116.

68 Ibid., 242-243. 
met uitzondering van medebedrijfsleidster Maria Muyssen en van Maria Verhelst, schoondochter van de bedrijfsleiders.

Doordat de werknemers van de fabriek in Langemark in drukke periodes bijsprongen in Wijtschate en beide ploegen tijdens de Tweede Wereldoorlog samenwerkten, konden ervaringen uitgewisseld worden tussen de werknemers. Hoewel een open leeromgeving volgens De Geus bijdraagt aan de capaciteit tot innovatie leidde dit hier niet tot vernieuwingen. Er was geen ruimte voor innovatieve ideeën van de werknemers, enkel die van de bedrijfsleider telden. Joseph Dumoulin bouwde rond 1948 de 'Dumpy', een kleine, gemotoriseerde driewieler voor personenvervoer. Er werden een drietal van dergelijke wagentjes geproduceerd, die allemaal verkocht werden. ${ }^{69}$ Deze uitvinding was, net als de vrachtwagens op gas, een radicale innovatie die Dumoulin als innovator introduceerde, maar ook hier bleef het bij 'spielerei' waarvan de economische mogelijkheden niet verkend werden. Het was een activiteit in de marge zonder impact op het bedrijf.

In deze periode lijkt op alle vlakken een relatief grote capaciteit tot innovatie aanwezig te zijn geweest in steen- en buizenbakkerij Dumoulin. De effectieve graad van innovatie bleef echter beperkt, met vooral vernieuwingen die door een late majority of late adopters in de sector werden overgenomen. Dit vertaalde zich in de prestaties: het bedrijf kende een periode van bloei en consolidatie (survival en longevity). De vruchten werden geplukt van de sterke inbedding in de lokale samenleving tijdens de Tweede Wereldoorlog, met de opbouw van politiek kapitaal als burgemeester (embeddedness en reputation). Daarnaast behield het bedrijf vooral haar goede reputatie (reputation) en bestendigde ze haar sociaal en economisch kapitaal (sustainability).

\section{Vernieuwing: een tunneloven in Langemark (196o-1970)}

Vanaf de jaren 196o kwam de markt onder druk te staan door de opkomst van goedkoper geproduceerde stenen, cementstenen en betongewelven. De Meesenbalken werden uit de markt geconcurreerd. Bovendien wijzigden vernieuwingen in de sector het hele productieproces grondig. Door een andere preparatie van de klei hoefde deze niet langer te overwinteren. De techniek die Dumoulin toepaste, waarbij de restwarmte van de bakoven gebruikt werd om de stenen te drogen, 
vond nu breder ingang. De vormelingen werden niet langer in de zon of in halfopen loodsen gedroogd maar in speciale droogovens waar die restwarmte gekanaliseerd werd. Zo kon de productietijd sterk ingekort worden. Bovendien werden de ringovens vervangen door tunnelovens waardoor het productieproces voor een groot deel geautomatiseerd werd en de productiecapaciteit opgedreven. De tunneloven was al in 1874 uitgevonden, maar was toen nog te complex. Omdat een tunneloven veel gemakkelijker te automatiseren was dan een ringoven, werd midden twintigste eeuw uiteindelijk toch massaal op deze productiemethode overgeschakeld. Met de tunneloven kon het bakproces nauwkeurig worden geregeld en werd de productiesnelheid verhoogd. ${ }^{\circ}$

Dumoulin reageerde hierop door ook in zijn bedrijf het productieproces te innoveren. In de buizenbakkerij Dumoulin in Wijtschate bleef een grondige modernisering uit, maar in de steenbakkerij in Langemark vonden in de jaren 1950-196o wél grote veranderingen plaats. In 1953 vroeg Joseph Dumoulin toestemming om zijn 'mekanieke steenbakkerij' te mogen verplaatsen en omvormen. De bedoeling was om zijn bedrijf te herbouwen tot een permanente steenbakkerij met een tunneloven, droogloods, schouw, machine- en productieruimtes, twee bovengrondse mazouthouders en een dieselmotor. ${ }^{71}$ Als early adopter van deze radicale innovatie, volgens de waardering binnen het model van Foster en Kaplan, trok de bedrijfsleider voor het ontwerp van de tunneloven naar de Verenigde Staten om dergelijke ovens te bestuderen. Hij paste het ontwerp vervolgens naar eigen behoefte aan. Er werd naarstig gebouwd waardoor de tunneloven in 1961 klaar was om in productie te gaan. Het smalspoor voor het transport van de stenen werd in één beweging mee weggehaald en vervangen door 'Spoetniks', gemotoriseerde wagentjes geconstrueerd door Joseph Dumoulin. De stenen konden zo sneller en gemakkelijker verplaatst worden..$^{72}$

De tunneloven bleek echter niet te voldoen: de stenen droogden te snel of onvoldoende waardoor ze barstten. Doordat Joseph Dumoulin te veel risico's genomen had en het ontwerp van de tunneloven volgens zijn eigen inzichten aangepast had zonder een expert te raadplegen, faalde de innovatie. De stenen bleken niet van goede kwaliteit en het productiesysteem kwam nooit tot volle ontwikkeling. Joseph Dumou-

\footnotetext{
70 Mostaert, 'Klei en maatschappij', 48-49; KNB, Van klei tot baksteen en meer, 3-4, 10; De Somer, Van klei tot baksteen, 52; De Niel, Gevormd, gedroogd, 20; Peirs, Uit klei gebouwd, 139-140.

71 Gemeentearchief Langemark-Poelkapelle, Dossiers Gevaarlijke, ongezonde en hinderlijke inrichtingen, 19530911_Dumoulin_kl1.

72 LA, DbdM, interview Koenraad Dumoulin; PA D, map 3, foto's van de 'Spoetniks'.
} 
lin kon voor het probleem geen goede oplossing vinden, waardoor zijn steenbakkerij de concurrentieslag met bedrijven in Zonnebeke en Ieper verloor. ${ }^{73}$ De enige grootschalige innovatie in het productieproces die steen- en buizenbakkerij Dumoulin gedurende haar levensloop doorvoerde, bleek helaas weinig succesvol.

In de jaren 1960-1970 stellen we slechts een beperkte capaciteit tot innovatie vast, die resulteerde in een lage graad van daadwerkelijke innovatie. In Wijtschate werd gewoonweg niet geïnnoveerd. Zo kwam er geen antwoord op nieuwe producten die de eigen producten uit de markt duwden. Samen met de onsuccesvolle radicale procesinnovatie van de tunneloven in Langemark had dit een grote impact op de prestaties van het bedrijf. Vooral de reputatie raakte zwaar beschadigd: het bedrijf kreeg de naam bakstenen van mindere kwaliteit te leveren (reputation). Niet enkel het sociale kapitaal maar ook het economische kapitaal van het bedrijf kende zware klappen door de mislukte investering (sustainability). We stellen vast dat het bedrijf op verschillende aspecten van performance die Colli identificeerde slecht presteerde.

\section{De boeken toe (1970-1981)}

In de hele grofkeramische sector leidde de automatisering tot een herstructurering van het industriële landschap. Er verdwenen heel wat bedrijven terwijl andere bedrijven een schaalvergroting kenden. ${ }^{74}$ Toen pvc-buizen rond de jaren 1960-1970 vanuit Nederland massaal de markt veroverden, kon de buizenbakkerij in Wijtschate daar niet mee concurreren. De 'plastieken' buizen waren heel wat goedkoper en door hun flexibiliteit en lengte konden ze veel sneller en gemakkelijker geplaatst worden. Hoewel steen- en buizenbakkerij Dumoulin de druk op de markt voelde, slaagde het bedrijf er niet in om daar adequaat op de reageren. De producten werden niet vernieuwd, het businessmodel bleef hetzelfde en de marketing bleef achterwege. In tegenstelling tot eerdere periodes lijkt nog maar weinig reclame te zijn gemaakt. Voormalige werknemers hebben geen weet van advertenties, folders of reclamepanelen. Volgens hen verliep de enige publiciteit via mondtot-mondreclame. Bovendien raakten de kleiputten stilaan uitgeput. Samen met de economische crisis van de jaren 1970 leidde dit alles ertoe 
dat de buizenbakkerij in Wijtschate omstreeks 1975 de deuren moest sluiten. De hoofdzetel in Langemark kon nog wat langer produceren.

Joseph Dumoulin ondernam nog enkele koortsachtige pogingen om het familiebedrijf te redden, door mogelijkheden voor transformationele innovaties te onderzoeken. Hij diende een vergunningsaanvraag in voor de omschakeling van de oven van de steenbakkerij naar een oven voor de verbranding van huisvuil. Diverse gemeentelijke overheden in de streek waren geïnteresseerd, maar de provinciale overheid uitte haar bezorgdheid over het ontwerp voor de oven en wees de aanvraag uiteindelijk af op basis van milieuoverwegingen. ${ }^{75}$ Ook het dempen van de kleiputten met afval stuitte op milieuproblemen. De uitgeputte kleiputten werden al sinds de jaren 1940 of 1950 beschikbaar gesteld voor het dumpen van afval. ${ }^{7} \mathrm{Al}$ in de jaren 1960, maar zeker in de jaren 1970 en 198 o bracht dit de familie Dumoulin steeds meer in conflict met de omwonenden en de gemeente. ${ }^{77}$ Bovendien bood het uitbaten van de vuilnisbelten geen perspectieven voor de langere termijn.

Dumoulin probeerde daarnaast ook in te spelen op de energiekwestie die de samenleving in haar greep hield door de oliecrises in de jaren 1970. Hij ontwierp een woonmolen, waarbij hij het energieprobleem probeerde op te lossen door gezinnen in windmolens te huisvesten. Daarnaast informeerde hij naar de mogelijkheden voor hydro-elektrische installaties. Deze uitvindingen en ideeën vonden echter nauwelijks gehoor en werden nooit gerealiseerd. $7^{8}$

Door de aanhoudende problemen met de tunneloven in Langemark werd ook deze productie-eenheid omstreeks 1979-1980 stilgelegd. Na het overlijden van oprichter Joseph Dumoulin in 1981 viel definitief het doek voor steen- en buizenbakkerij Dumoulin. ${ }^{79}$ De steen- en buizenbakkerij kon in de jaren 1970 niet langer weerstaan aan de veranderende externe omstandigheden, zoals de algemene economische recessie, de druk van de markt - zowel van concurrenten als nieuwe producten - en de uitputting van de grondstoffen. De capaciteit tot innovatie was in deze periode erg beperkt. Het personeel werd aan de deur gezet omdat de verkoop afnam. Dit leidde tot een verzwakking van

77 PA WVl, VG, A7 GB PB 2001/48q; id., A7 GB PB 2001/6oa; id., A7 GB PB 2001/73h; id., A7 GB PB 2002/131m; id., A7 GB PB 2002/153d; id. A3/A5/A7 GB PB 2004/41e.

78 PA D, dossier 'molen'.

79 BWP, 'Beroep tegen bescherming buizenfabriek Dumoulin', Het Nieuwsblad, 23 augustus 200o; LA, DbdM, interview Roland Debeuf; interview Koenraad Dumoulin; interview Jean-Marie Callewaert; interview Jan Dumoulin. 
de identiteit van het bedrijf. Bovendien hadden de werknemers weinig inbreng, waardoor er nauwelijks sprake was van een open leeromgeving. Daarnaast kwamen er steeds meer conflicten met de omgeving en droogden ook de financieringsmogelijkheden op. De bedrijfsleider ondernam pogingen die tot een volledige omschakeling van het bedrijf zouden leiden, maar effectieve innovatie bleef uit. Het lijkt er zelfs op alsof er met een zekere gelatenheid naar de concurrentie en de aftakeling van het bedrijf werd gekeken. Het bedrijf slaagde er dan ook niet in om te overleven. Hoewel de familie bij de voormalige werknemers nog steeds over enig sociaal kapitaal beschikte (embeddedness), raakten de reputatie en sustainability van het bedrijf blijvend beschadigd.

Door de bouwcrisis in de jaren 1980 moesten niet veel later ook heel wat Kortrijkse steen- en pannenbakkerijen de deuren sluiten. De voortdurende technische ontwikkelingen zorgden voor een verdere schaalvergroting, automatisering en modernisering. ${ }^{80}$ Steen- en buizenbakkerij Dumoulin was zeker niet het laatste bedrijf dat zich niet kon aanpassen aan de veranderende omstandigheden. Anno 2021 zijn enkel het middelgrote bedrijf Dumoulin Bricks en de multinational Wienerberger nog actief in West-Vlaanderen.

\section{Besluit}

Steen- en buizenbakkerij Dumoulin was actief in een steeds veranderende context waarin de impact van de wereldoorlogen, maar bovenal van de steeds toenemende globalisering zich liet voelen. Gedurende zijn levensloop kende het bedrijf een vrij hoge capaciteit tot innovatie, die echter stelselmatig afnam. Hoewel er een ruime tolerantie was voor activiteiten in de marge bleven initiatieven op dit gebied voorbehouden aan de bedrijfsleider. De aanwezige capaciteit tot innovatie werd slechts zelden en dan nog mondjesmaat vertaald in effectieve innovatie. Deze innovaties waren voornamelijk incrementele vernieuwingen. Vooral tijdens interbellum werd ingezet op productinnovatie door nieuwe producten zoals de drainagebuizen, holle stenen, Meesenbalken en schuilplaatsen in het aanbod te introduceren. De procesinnovatie bleef echter beperkt. Toen met de tunneloven uiteindelijk toch een grootschalige procesinnovatie in gang werd gezet, mislukte dit door te weinig externe expertise aan te trekken. Als early adopter van een der- 
gelijke grootschalige radicale innovatie nam Joseph Dumoulin te veel risico's. Bovendien vond de innovatie plaats in een periode van veel externe druk van de markt en een afnemende innovatiecapaciteit van het bedrijf, waardoor een dergelijke fout nog moeilijk rechtgezet kon worden. Daar komt bij dat het bedrijf nauwelijks aan vermarktingsinnovatie deed. Het businessmodel, de aangesproken markt en de prijszetting bleven gedurende de hele periode nagenoeg hetzelfde. Vanaf de jaren 1960 is er zelfs, voor zover bekend, geen sprake meer van enige marketing. Ook op organisatorisch vlak vond nooit enige innovatie plaats. De organisatorische structuur van het bedrijf bleef gedurende de hele levensloop precies dezelfde.

Steen- en buizenbakkerij Dumoulin bleef een lokaal verankerde kmo en familiebedrijf. De belangen van de familie en het bedrijf vielen samen. In de loop van de jaren 1950 en 1960 werden twee zoons, Antoon en Jan Dumoulin, het bedrijf ingeloodst om voor opvolging te zorgen. Net als in andere kleine familiebedrijven in Oost- en WestVlaanderen vallen ook voor de steen- en buizenbakkerij Dumoulin de gehechtheid aan het eigen bedrijf en de conservatieve financiering op. ${ }^{81}$ Er was voldoende financiële capaciteit om een grote investering als de tunneloven te bekostigen. Maar door de rigide houding tegenover de input van extern kapitaal waren de middelen voor innovatie toch vrij beperkt. Toen de druk van de markt te groot werd, werden schulden opgebouwd, die het bedrijf verhinderden om nog onafhankelijk en flexibel te ageren.

Steen- en buizenbakkerij Dumoulin kende heel wat kansen en uitdagingen. Onmiddellijk na de oprichting slaagde het bedrijf erin om lokaal verankerd te raken en sociaal kapitaal op te bouwen. In de periodes nadien kon de bedrijfsleider door de capaciteit tot innovatie en dankzij enkele daadwerkelijke innovaties verschillende strategieën aanwenden om zijn economisch en sociaal kapitaal verder uit te bouwen. Er werd een stevige reputatie opgebouwd, het bedrijf was goed ingebed in zijn omgeving en het geheel getuigde van een zekere sustainability. Op het hoogtepunt vertaalde dit zich zelfs in politiek kapitaal.

Zolang de markt grotendeels lokaal bleef, kon het bedrijf op de veranderende omgeving inspelen. Toen er grotere uitdagingen op het toneel verschenen, zoals de sterke concurrentie van goedkoop vervaardig-

81 G. De Vylder, 'Een aanzet tot een ontwikkelingseconomische benadering van de bedrijfsgeschiedenis aan de hand van de case-study Brepols te Turnhout', in: G. Devos (red.), Bedrijfsgeschiedenis een uitdaging. Studiedag naar aanleiding van 25 jaar Centrum voor Bedrijfsgeschiedenis UFSIA - Universiteit Antwerpen (Brussel 1998) 56. 
de nieuwe producten uit het buitenland, kon steen- en buizenbakkerij Dumoulin hier steeds moeilijker mee omgaan. Toen de druk van de markt te groot werd en ook het wettelijke en culturele kader stringenter werden, raakte de reputatie van het bedrijf beschadigd. Ondanks de lokale verankering van het bedrijf en het ondernemerschap van de bedrijfsleider verloor steen- en buizenbakkerij Dumoulin veel van haar sociaal en economisch kapitaal. Uiteindelijk bezweek het bedrijf onder de technologische veranderingen en de internationale uitdagingen. Net als zoveel andere bedrijven werd steen- en buizenbakkerij Dumoulin het slachtoffer van haar moeilijkheden om afdoende te reageren op de sectorale herschikkingen.

De reconstructie van de levensloop van steen- en buizenbakkerij Dumoulin maakt duidelijk dat het voorgestelde theoretische kader gebruikt kan worden om een specifiek bedrijf te analyseren vanuit verschillende invalshoeken en niveaus. De combinatie van de parameters voor performance geformuleerd door Colli, gekoppeld aan de algemene theorie van De Geus, aangevuld met een waarderingskader voor innovaties uit de theorie van creatieve destructie (Foster en Kaplan) en de diffusietheorie van Rogers, is daarbij een waardevol instrument gebleken omdat er verschillende bronnen en methodes in samengebracht kunnen worden, waaronder bedrijfsarchief, overheidsinformatie, mondelinge getuigenissen en methodes van de industriële archeologie. In de voorgestelde theorie is er aandacht voor de hele levensloop van een bedrijf. De verschillende levensfasen van het bedrijf kunnen aan dezelfde vragen onderworpen worden en zo kan een beeld geschetst worden van de evolutie die het bedrijf doormaakte.

De hypothese dat steen- en buizenbakkerij Dumoulin in periodes met een hogere capaciteit tot innovatie ook een hogere graad van feitelijke innovatie kende, beter in staat was in te spelen op de externe factoren en daarmee ook betere prestaties realiseerde, blijkt echter niet volledig correct. Er kon geen eenduidige relatie worden vastgesteld tussen de veranderende omgeving, de capaciteit tot innovatie, de effectieve graad van innovatie en de prestaties van het onderzochte bedrijf. Tot de jaren 60 is dit verband wel enigszins vast te stellen, hoewel een grote capaciteit tot innovatie niet steeds tot een hoge graad van innovatie leidde. Daarna bleef er een vrij gelijkaardige capaciteit tot innovatie bestaan en waren er wel pogingen om tot een hoge graad van innovatie te komen, maar dit resulteerde niet in goede prestaties. Daarvoor was de druk van de internationale markt te groot. Vermoedelijk dient de waardering van de capaciteit tot innovatie en effectieve graad van innova- 
tie strenger te gebeuren in de context van een geïnternationaliseerde markt dan in een lokale markt. Deze nieuwe hypothese vergt verder onderzoek.

Desondanks liet het theoretisch kader toe om de levensloop van het bedrijf grondig te evalueren en naar waarde te schatten. Door het schaarse bronnenmateriaal bleek het moeilijk om de levensloop van steen- en buizenbakkerij Dumoulin in de bredere economische ontwikkelingen te plaatsen en dient de waardering van de prestaties en innovaties met grote omzichtigheid te gebeuren. Toch is het mogelijk gebleken om ook wanneer er weinig bedrijfsarchief en bronnen voorhanden zijn een analyse te maken. Bovendien laat het kader als werkinstrument veel ruimte voor de specifieke historische context waarin het bedrijf werkzaam is en voortdurend mee in interactie treedt. Het waarderingskader voor de effectieve innovaties biedt de mogelijkheid om een inschatting te maken van het ondernemerschap binnen het bedrijf. De onderzochte casus bood helaas niet de mogelijkheid om de bruikbaarheid van de theorie voor kwantitatief onderzoek te toetsen.

Micro-historische case studies volgens eenzelfde analytisch kader kunnen de mogelijkheid bieden om als bouwstenen bij te dragen tot sectorale en regionale syntheses. Of dit raamwerk ook de mogelijkheid biedt om tot een bredere, overkoepelende synthese te komen, valt nog af te wachten.

\section{About the author}

Kim Descheemaeker (1993) studeerde in 2016 af als Master in de Geschiedenis aan de Universiteit Gent. Dat jaar ging ze aan de slag bij $\mathrm{CO}_{7}$, het intergemeentelijk samenwerkingsverband voor cultuur en erfgoed in de Zuidelijke Westhoek. Sinds 2017 werkt ze als historical researcher bij Liberas, het centrum voor de geschiedenis van het vrije denken en handelen. Ze publiceert in diverse tijdschriften, zowel voor een academisch als een breder publiek.

Email: kim.descheemaeker@liberas.eu 
